\title{
Problems in Agricultural Cooperation Development in Russia (Case Study of Samara Region)
}

\author{
R.V. Nekrasov ${ }^{1}$, E.P. Gusakova ${ }^{1, *}$ and E.P. Afanaseva ${ }^{1}$ \\ *Corresponding author: elengus@inbox.ru \\ ${ }^{1}$ Samara State University of Economics, Samara, Russia
}

\begin{abstract}
Agricultural cooperation of small farms in the world occupies a special rank. It has a great potential to expand the production and consumption of domestic agricultural products. It is an important condition for preservation and development of rural lifestyles, the development of large farms through cooperation and (or) integration. Russian and international experience suggests that cooperation is one of the most effective mechanisms for adapting agriculture to the faltering economy, due to the increased competition in national and world food markets, international sanctions and other factors. The purpose of the study is to identify the problems and prospects in the agricultural cooperation development in Russia, in general, and in Samara region, in particular, in the context of the development of world agriculture. The authors have used general scientific and special methods and techniques of economic research. The study has shown that, on the one hand, Russia lags far behind developed countries in agricultural cooperation, but, on the other hand, thanks to the agricultural cooperation development, Russia will be able to increase and strengthen its competitive advantages in the world agricultural products market. According to the results of the study, the authors have concluded that the greatest effect of agricultural cooperation in Russia and its regions is provided by the financial and ideological state support.
\end{abstract}

Keywords: agriculture, agricultural consumer cooperation, agricultural production cooperation, farming, government support, private subsidiary farm.

\section{Introduction}

The most important way for economic growth in the agricultural sector and the solution of social problems in rural areas is the development of agricultural cooperation, which strengthens the agricultural producers 'market position (especially small farms), and allows them to maximize returns. It has a positive impact on the welfare of not only the members in a cooperation group, but in general, on living standards increase in rural areas. In addition, it plays an important role in preservation and development of rural lifestyles, and preventing the extinction of some territories.

According to the Decree of the President of the Russian Federation (May 7, 2018, N 204) "National Goals and Strategic Objectives in the Russian Federation Development for the Period up to 2024", the Federal Project "Farmers Support System and Rural Cooperation Development" under the National Project "Small and Medium-Sized Entrepreneurship and Support for Individual Entrepreneurial Initiative" is under approval. The President of the Russian Federation in his Address to the Federal Assembly emphasized the role of small farms (family farms, subsistence farming, new agricultural entrepreneurs), including agricultural cooperation in increasing the exports of food and highvalue products. It gives hope for further protectionist state policy to the agricultural cooperation development and other forms of agricultural business.

Cooperative formations let isolated small farms combine their resources (labor, land, money, transport, sales, etc.) for more efficient use. In modern conditions, small agricultural producers at almost all stages of agricultural activity are faced monopolists or oligopolists (banks, leasing companies, electricity and machinery suppliers, transport companies, etc.).

Worldwide, cooperation is known as an effective tool to solve social and economic problems. In many market economies, farmer cooperatives play a significant and, in some cases, dominant role in interaction between agriculture with other economic sectors and the agricultural industry development. In Northern Europe, the Netherlands, Ireland and Japan, almost all primary agricultural producers are in the cooperative movement. In the European Union, cooperatives produce up to $60 \%$ of food products. In the United States, cooperatives account $30 \%$ of all commercial agricultural products. Cooperatives in Japan market about $90 \%$ of all agricultural products and provide farmers with about $80 \%$ of the required means of production [1].

The effectiveness of agricultural cooperation and its contribution to the sustainable development of the region under study are reflected in the researches of E. Nikolaeva [2], Cláudia Diasa and Mário Francob [3], K.S. Amanor and Sérgio Chichava [4].

\section{Problem Statement}

In recent years, analysis of the agricultural cooperation development in Russia and its regions revealed a number of macroeconomic problems associated with the state support volume, and weak interaction with development institutions 
and imperfection of legislation on cooperation. In addition, there are microlevel problems: imperfection of mechanisms of internal cooperative regulation, low level of awareness of rural residents about cooperation benefits, and lack of trust among potential cooperation participants to each other.

\section{Research Questions}

To determine the current state, problems and prospects of agricultural cooperation development in Samara region, it is necessary to identify the state regulation of agricultural cooperation and infrastructure, and institutional environment of its functioning. It is important to consider the regional support systems of the agricultural consumer cooperation development and its transformation.

\section{Purpose of the Study}

The purpose of the study is to analyze the level of the agricultural cooperation development in Russia and in the particular region. The assessment of the state and regional programs of agricultural cooperation development, to identify the conditions and obstacles in the development of agricultural cooperatives, and to propose ways for the successful agricultural cooperation development in Russia and Samara region, taking into account the best world experience.

\section{Research Methods}

To complete the tasks of the study, the following methods were used: dialectical, abstract-logical, comparative analysis, research of economic and social processes on the basis of statistical analysis. Information base of the study is data of the Federal State Statistics Service in Russia, the Ministry of Agriculture of the Russian Federation, the Ministry of Agriculture and Food of Samara region, portals of infrastructure organizations dealing with the development of agricultural consumer cooperatives on the Internet.

\section{Findings}

Interest in agricultural cooperation has dramatically increased after Russian President Vladimir Putin noted in his Address to the Federal Assembly (December 1, 2016) that to help farmers enter the market, special attention should be paid to supporting agricultural cooperation. This note has accelerated the formalistic supporting work. By order of Minister of Agriculture of the Russian Federation Alexander Tkachev, the plan to create in 2016-2017 agricultural cooperatives, taking into account regional features of agriculture and territorial placement of small and medium-sized agricultural producers, were brought to the regions. As a result, 570 agricultural cooperatives have been established, including 57 cooperatives in Lipetsk region, 32 in the Republic of Tatarstan, 23 in the Republic of Sakha (Yakutia), 21 in Volgograd region and 10 in the Republic of Dagestan [5].

State support for agricultural consumer cooperation in Russia is currently carried out mainly in the form of interest rate subsidization under state programs for the agriculture development and grant support for development of material and technical resources. At the same time, state credit financing support for agricultural consumer cooperatives is constantly decreasing (from $394 \mathrm{mln}$ rubles in 2010 to $54 \mathrm{mln}$ rubles in 2016) [5]. The main focus is now on grant support for cooperatives. According to the Ministry of Agriculture of Russia, 252 cooperatives received $1300 \mathrm{mln}$ rubles of grant funds from the Federal budget in 2015-2016, and $1494.6 \mathrm{mln}$ rubles in 2017. Dairy cooperatives received $38 \%$ of the total amount, meat cooperatives $-35 \%$, potato-growing and vegetable cooperatives $-20 \%$. Fruit cooperatives, fish farming cooperatives, wild berries and mushrooms farming cooperatives received $2 \%$ of the amount of the grant support. The average grant amount to a cooperative was $10.76 \mathrm{mln}$ rubles that is $35.5 \%$ higher than in 2016 . The main grant support expenditure in 2017 was the equipment purchase for agricultural products processing (45\% of recipients) and the production facilities construction (32\%) [5].

Without dispute, the result of state support for the cooperative movement in rural areas is more strategic than direct (village preservation). While involving in economic processes, private subsidiary farms will expand, create unions, cooperatives and unite with other enterprises. From the point of view of public administration, it is much more effective to support and develop not many small farms, but their organized cooperatives. With the help of a multi-level system of agricultural consumer cooperation, it is possible to implement state agricultural programs and solve strategic tasks, in particular food security, public purchases and import substitution.

Currently, agricultural cooperative activity is regulated by the Federal Law "Agricultural Cooperation", December 08, 1995, N 193-FL (as in force in 2016, July 03) [6]. The law establishes the basic principles for an agricultural cooperative to be organized and operate. Legal, economic and social bases for formation and activity of the consumer societies and their unions, that make consumer cooperation of the Russian Federation, are defined by the Federal Law 
"Consumer Cooperation (consumer societies, their unions) in the Russian Federation" (as in force in 1997, July 17, N 97-FL with changes in 2013, July 2) [7].

The cooperative movement in the sphere of consumer cooperation in agriculture was promoted by the State Program of Agricultural Development and Regulation of Markets of Agricultural Products, Raw Materials and Food in 20132020 [8]. It provides the resource support for the development program in agricultural cooperation with the help of grant support for agricultural cooperatives to increase material and technical resources, which is especially important for innovative growth of newly established, economically weak industries and small farms.

According to Rosstat (January 1, 2017) 5839 agricultural consumer cooperatives, including 1032 processing cooperatives, 1410 supply-marketing cooperatives, 1381 credit cooperatives, 813 serving cooperatives and 1203 others were established in 73 entities of the Russian Federation. The share of small businesses in the total volume of agricultural production accounted to $47 \%$ of total production in 2016, according to Rosstat. Regional agricultural cooperation systems are successfully developing in Lipetsk, Volgograd, Saratov, Tyumen, Orenburg, Rostov, Belgorod, Kaluga regions, the Republic of Tatarstan, Mordovia, Chuvash Republic, the Zabaikalye Territory, and Krasnoyarsk region [9]. At the same time, there is a territorial irregularity in the cooperative distribution. There are regions where the number of cooperatives amounts to hundreds. The most successful cooperation develops in Lipetsk region (711), the Republic of Sakha (Yakutia) (159) and Tyumen region (112). At the same time, in Murmansk, Magadan, Evreyskaya regions and the Kamchatka territory there is no going cooperative [10].

In contrast to the world practice with the predominance of agricultural consumer cooperatives, engaged in economic service of their members, production agricultural cooperatives prevail in Russia. Many scientists speak for their favor, considering the production cooperative as the most acceptable economic form in rural areas and noting their positive characteristics [11].

In Samara region, cooperative relations in rural areas are developing within several models and organizational systems. The most important are agricultural cooperatives and consumer societies. By January 1, 2017, 38 agricultural consumer cooperatives had been registered in Samara region, which is less than in 2013, when there were 56 consumer cooperatives. According to the municipal districts in Samara region, 15 agricultural consumer cooperatives operated in 13 municipal districts of Samara region in 2017, including 11 credit cooperatives, 2 processing cooperatives and 2 supply and marketing cooperatives (data obtained on official request to the Ministry of Agriculture and Food of Samara region). It is definitely not enough for the region with a population of more than $3 \mathrm{mln}$ people, where one in five is a rural resident, and the volume of agricultural production is more than $83.2 \mathrm{bln}$ rubles.

According to Point of Law 4 of Instruction List of the President of the Russian Federation (following the results of the business trip to Krasnodar region (March 03, 2018) N PR-529, the Ministry of Agriculture and Food of Samara region developed the work flow chart for the development of agricultural and consumer cooperation in 2018-2020. According to this chart, it is planned to establish annually at least 3 new agricultural consumer cooperatives in 20182020. The number of agricultural consumer cooperatives, which will be provided with information and consulting services in 2018, is 10 , in 2019 - 15, in 2020 - 20. Benchmarks for the development of agricultural consumer cooperatives, which receive grant support for the material and technical resources development, will ensure the annual creation of new permanent jobs (at least 5) and growth of agricultural products volume, sold by agricultural consumer cooperatives, will be $10 \%$ annually [12].

In 2018, the Competence Center in agricultural cooperation of Samara region was determined. This is the StateFinanced Institution of Further Vocational Education "Samara-ARIS", as the Institution has all opportunities and resources to complete the tasks. The main task of the Competence Center is information sharing, consulting and methodological assistance to cooperatives and farms; supporting their business plans and feasibility studies, applications for subsidies from the Federal and regional budgets; holding of seminars and sessions; advising on the use of SME Business Navigator Portal; assistance to small and medium-sized rural businesses in obtaining credit and guarantee support, etc.

Expert consultation and discussion on agricultural cooperation problems with the heads of farms and private farms of Samara region has revealed a great interest of the agricultural community that emphasizes the relevance of the cooperation development in rural areas and readiness to participate in the cooperative movement. At the same time, the objective factors hindering the active development of agricultural consumer cooperation in the region are identified: low level of producers` confidence to each other, lack of public awareness of cooperation benefits, lack of qualified personnel and financial resources.

Modern cooperation is an association of entrepreneurs, who are interested in increasing the added value of their raw materials or products and in adjusting supply situation. Generalization of the main resources, working order regulation, search for leaders to form initiative groups, use of all the advantages of working in cooperation and making a profit, these are the main points in the cooperation development. The basic limiting factor is trust between participants and cooperatives as a form of work. It can be eliminated only by advocacy work. For this purpose, special seminars for new cooperatives are held in the region and cooperation is promoted. Information support of the population about cooperation benefits is carried out by informing through media, municipalities administration, the Center for the Cooperative Development. The infrastructure of information and consulting support of agricultural cooperatives was established in Samara region: The State-Financed Institution of Further Vocational Education "Samara-ARIS", Association of farms, farmers and agricultural cooperatives in Samara region, Samara Regional Audit Union of Agricultural Cooperatives "Middle Volga". Training seminars "Effective activities of the agricultural cooperative" held by Samara Regional Audit Union of Agricultural Cooperatives "Middle Volga", which are attended by representatives 
of the coordinating councils for the development of cooperatives, managers and accountants of agricultural cooperatives of all municipal districts of the region, eliminate the qualified personnel shortage. Currently, more than 70 enterprises from 22 municipalities of the region successfully cooperate with Revsoyuz.

The State Program of Samara region "Development of Agricultural and Consumer Cooperation in Samara region in 2013-2020", which aims to develop agricultural and consumer cooperation in Samara region, will compensate the lack of financial resources. The financing of the State Program activities at the expense of the regional budget in 2013-2020 was approved in the amount of $331.01 \mathrm{mln}$ rubles (table 1).

Table 1. State support for the consumer cooperation development in the agricultural sector of Samara region in 2013-2017

\begin{tabular}{|c|c|c|}
\hline Mode of supply & $\begin{array}{c}\begin{array}{c}\text { Volume } \\
\text { of } \\
\text { support, } \\
\text { mln rub }\end{array} \\
\end{array}$ & Results \\
\hline $\begin{array}{l}\text { Subsidizing the acquisition } \\
\text { costs for technological } \\
\text { equipment, } \\
\text { transport for harvesting, } \\
\text { agricultural } \\
\text { processing, storage, meat and } \\
\text { milk in households }\end{array}$ & 141.0 & $\begin{array}{l}48 \text { trucks, } 33 \text { milk trucks, } 14 \text { milk cooling tanks, } \\
\text { more than } 200 \text { units of food and technical } \\
\text { equipment, } 10 \text { thousand tons of milk }(146 \% \text { by } \\
\text { 2012), and } 0.5 \text { thousand tons of meat }(120 \% \text { by } \\
\text { 2012) were purchased. }\end{array}$ \\
\hline \multicolumn{3}{|r|}{2017} \\
\hline $\begin{array}{l}\text { Reimbursement of expenses } \\
\text { for the purchase of equipment } \\
\text { and over-the-road truck } \\
\text { transport }-3.6 \mathrm{mln} \text { rubles, } \\
\text { meat and milk processing or } \\
\text { sale to processing enterprises } \\
-17.4 \text { mln rubles. }\end{array}$ & 21.0 & $\begin{array}{l}10 \text { thousand tons of milk and almost } 330 \text { tons of } \\
\text { meat were purchased by farms, which exceeds the } \\
\text { planned values of } 3.5 \% \text { and } 73.7 \% \text {, respectively. } \\
\text { Specialized over-the-road truck transport for a total } \\
\text { of more than } 23 \text { mln rubles were purchased. } \\
\text { Cooperative organizations paid tax payments to the } \\
\text { budgets of all levels in the amount of more than } \\
200 \text { mln rubles. More than } 9.5 \text { rubles of } \\
\text { compulsory levies were paid for one ruble of the } \\
\text { budget funds received. }\end{array}$ \\
\hline
\end{tabular}

Source: compiled by the authors [13].

These actions will let, in the medium term, significantly increase the purchase volume of agricultural products, expand the stock, improve the quality of food and trade services to the rural population. The Agro-Industrial Park (opened in the regional center in September 2018) with the capacity of 11 thousand tons of agricultural products storage will offer additional opportunities to the cooperators. The low level of access to credit resources remains relevant, as agricultural credit cooperation is practically excluded from the state supporting measures and lending in banks.

Problems in agricultural cooperation development in Samara region are the subject of constant active discussions. The legislation in cooperation is analyzed, and proposals for its improvement are developed. In 2017, a working party was formed under the Committee on Agriculture and Food in Samara Regional Duma to resolve problematic issues of agricultural cooperation development, requiring legislative regulation. Thanks to the team-work of deputies of the Duma, the Ministry of Agriculture and Food of Samara region, the "Middle Volga" Union and representatives of rural cooperatives, the following laws were elaborated and adopted by the State Duma of the Federal Assembly of the Russian Federation:

- The Federal Law N 207-FL (July 27, 2010) "Introduction of amendments to Chapter 23 Part 2 of the Tax Code of the Russian Federation" in terms of reducing the tax burden for shareholders of credit cooperatives,

- The Federal Law N 99-FL (April 20, 2015) "Introduction of amendments to Federal Law "Agricultural Cooperation" in terms of establishing a unified approach to the property formation sources of a credit consumer cooperative.

Agricultural cooperation can become an essential tool not only to achieve individual goals of consumers, employees of the cooperation system and shareholders and to increase their personal welfare and social security, but also to complete national tasks, priority national projects, purpose-oriented programs and to improve employment.

\section{Conclusion}

Experience in the cooperation development in the Russian Federation entities, in general, and in Samara region, in particular, shows that the following conditions are the necessary basis for successful cooperative development:

- legal framework aimed at creating optimal conditions for the cooperation development in the region, including the regional law or the program for development of cooperation and small business that take into account the regional characteristics,

- stable financial support for rural cooperatives, including small businesses,

- wide access to information, availability of the regional training center, methodological materials distribution on the cooperative formation and support, 
- use of administrative resources to monitor the cooperation development and rapid elimination of administrative barriers,

- regular cooperative personnel training, availability of the training center in the region,

- systematic approach to the development of all types of cooperatives and cooperation support institutions.

Agricultural cooperation needs not only state support, but both financial (tax benefits) and ideological one. We need to promote the ideas and ideals of cooperative movement and methodical work to explain the cooperation benefits in comparison with working in separated farms. In the context of toughening competition in the food markets, the development of agricultural production and consumer cooperation is a significant factor in the development of small and medium-sized agricultural enterprises.

\section{References}

1. Kuban agricultural wnformation and consulting center (Kuban IKTS), World experience in the agricultural cooperation development. Retrieved from: http://www.kaicc.ru/novoe-v-apk/peredovoj-opyt/mirovoj-opyt-razvitijaselskohozjajstvennoj-kooperacii. Accessed: 15.12.2018 (2018). [in Rus.].

2. E. Nikolaeva, Efficiency analysis of agricultural cooperation in Russia. Procedia - Social and Behavioral Sciences, 238, 364-373. DOI: 10.1016/j.sbspro.2018.04.013 (2018).

3. C. Dias, M. Franco, Cooperation in tradition or tradition in cooperation? Land Use Policy, 71, 36-48. DOI: 10.1016/j.landusepol.2017.11.041 (2018).

4. K.S. Amanor, S.Chichava, South-South cooperation, Agribusiness and agricultural development in Africa: Brazil and China in Ghana and Mozambique. World Development, 81, 13-23. DOI: 10.1016/j.worlddev.2015.11.021 (2016).

5. V.I. Tsoy, State support for small farms and agricultural cooperation. Report at the all-Russian meeting chaired by the Minister of agriculture of the Russian Federation. Retrieved from: http://apksakha.ru/assets/uploads/2017/07/07/pdf/TSOJ-PRAKTICHESKIJ-SEMINAR.pdf. $\quad$ Accessed: 15.12 .2018 (2017). [in Rus.].

6. Federal Law "Agricultural cooperation" 8.12.1995 N 193-FL. Retrieved from: http://base.garant.ru/10105638/\#ixzz5VJYNfbIjhttp://base.garant.ru/10105638/. Accessed: 15.12.2018 (1995). [in Rus.].

7. Federal Law "Consumer cooperation (consumer societies, their unions) in the Russian Federation" 17.07.1997 N 97-FL. Retrieved from: http:// base.garant.ru/11901260/ Accessed: 15.12.2018 (1997). [in Rus.].

8. Ministry of agriculture of the Russian Federation, State program of agricultural development in 2013-2020. Retrieved from: http://mcx.ru/activity/state-support/programs/program-2013-2020. Accessed: 15.12.2018 (2013). [in Rus.].

9. Ministry of Agruculture of the Russian Federation, State support for small farms and agricultural cooperation. Analytical report. Retrieved from: http://mcx.ru/upload/iblock/60b/60b94a4263967a0964524e180b693eb5.pdf. Accessed: 15.12.2018 (2017). [in Rus.].

10. The Association of peasant (farmer) farms and agricultural cooperatives of Russia (AKKOR), Resolution of the meeting on agricultural consumer cooperation: conclusions and recommendations. Retrieved from: http://www.akkor.ru/statya/4082-rezolyuciya-soveshchaniya-po-selhozpotrebkooperacii-vyvody-i-rekomendacii.html. Accessed: 15.12.2018 (2017). [in Rus.].

11. I. Minakov, Agricultural production cooperatives and their development prospects in Russia. Food And Processing Industry Technologies In Agroindustrial Complex. Products of Healthy Food, 3(17), 105-113. URL: https://cyberleninka.ru/article/n/selskohozyaystvennye-proizvodstvennye-kooperativy-i-perspektivy-ih-razvitiya-vrossii (2017). [in Rus.].

12. Analytical report. Agricultural cooperation. Samara - ARIS. Agro inform. Retrieved from http://www.agroinform.ru/index.php/selskoxozyajstvennaya-kooperacziya Accessed: 15.12.2018 (2017). [in Rus.].

13. R.V. Nekrasov, Agricultural policy of Samara region in terms of import substitution. Intelligence Innovation Investment, 2, 4-14. URL: http://intellekt-izdanie.osu.ru/arch/n2_2018.pdf (2018). [in Rus.]. 